\title{
EDITORIAL
}

\section{DIREITOS HUMANOS NA ATUALIDADE: UM MUNDO EM CRISE}

Preocupante é a ascensão do populismo dentro dos Estados Democráticos de Direito, em uma clara afronta e violação aos direitos humanos. Direitos esses que foram arduamente construídos e conquistados pela humanidade ao longo de períodos históricos e tiveram como ápice o fim da Segunda Guerra Mundial e a construção do Sistema Global de Proteção por meio da Organização das Nações Unidas, no século XX.

No século XXI, diferentemente do que imaginávamos, caminhamos para um cenário confuso e melancólico, ante as claras e manifestas violações aos direitos humanos por parte dos Estados.

Não obstante a comunidade internacional questione a efetividade na tutela dos direitos humanos dentro da ONU, em virtude da inexistência de mecanismos institucionalizados para buscarem a responsabilização internacional do Estado contra graves violações aos direitos humanos, a exemplo do que ocorre dentro do Sistema Interamericano de Proteção aos Direitos Humanos, verificamos que, guardadas as devidas proporções e dentro dos limites de atuação que o próprio direito internacional impõe, a ONU procura atuar eficazmente.

Resta ressaltar aqui o importante papel exercido pela sociedade civil organizada na defesa dos direitos humanos, de forma a dar publicidade às graves violações cometidas pelos Estados.

Em artigo de opinião escrito por Kenneth Roth (2017), ${ }^{1}$ alerta-se para a escalada dos regimes populistas dentro dos Estados Democráticos de Direito e o consequente retrocesso dos direitos humanos e sociais.

Adverte Roth que em decorrência da atual tendência de um retrocesso dos Direitos Humanos e perante as tensões existentes dentro da sociedade internacional, os conflitos armados (como é o caso da Síria) e a consequente crise humanitária ameaçam, seriamente, as conquistas históricas dos direitos humanos.

Certo é que, ao longo da história, a conquista dos direitos humanos foi, é e sempre será marcada por uma constante luta, visto que decorre de avanços e retrocessos por parte da sociedade, de acordo com os dizeres de Flávia Piovesan.

Todavia, se fizermos um comparativo histórico com os tristes acontecimentos advindos da Segunda Guerra Mundial em relação à crise humanitária vivenciada nos dias de hoje, os números demonstram que esta pode superar a do pós-Guerra.

\footnotetext{
1 HUMAN RIGHTS WATCH. Relatório Mundial 2017: Demagogos Ameaçam os Direitos Humanos. Trump e populistas europeus fomentam a intolerância e a discriminação. Washington, 12 jan. 2017. Disponível em: <https://www.hrw.org/pt/ news/2017/01/12/298861 >. Acesso em: 23 abr. 2017.
} 
Naturalmente, a crise humanitária tem como consequência os constantes processos migratórios e que se traduzem em somente uma das faces do triste período que vivenciamos atualmente no que diz respeito aos direitos humanos.

Infelizmente, neste triste cenário, os líderes mundiais e chefes de Estado procuram - cada vez mais - adotar políticas e condutas na defesa de seus interesses soberanos, à revelia de um ideal maior, o da proteção da pessoa humana, e passam a adotar atos e condutas extremadas, como é o caso da xenofobia contra os imigrantes.

Dita onda populista, que antes era experimentada nos países latino-americanos, atualmente passa a ser vivenciada dentro dos Estados Unidos da América, com Donald Trump e seu constante ataque aos direitos dos imigrantes, e na própria Europa, com a ameaça de governos extremamente nacionalistas e as ondas e políticas de xenofobia.

Dentro do triste cenário, temos ainda a Guerra Civil na Síria, a adoção de medidas autoritárias na Turquia e, na América do Sul, o avanço do populismo e a crise humanitária na Venezuela.

Diante de tais horrores, torna-se imperioso repensarmos a estratégia de ação na defesa dos próprios direitos humanos por parte dos Estados, da comunidade internacional e da própria Organização das Nações Unidas, como forma de tentar preservar os valores e direitos conquistados historicamente.

Naturalmente, as constantes ameaças de retrocessos aos direitos humanos também ocorrem no Brasil, e o mesmo Relatório de 2017 elaborado pela Human Rights Watch aponta para graves violações aos direitos humanos. Há que se destacar que o Brasil, enquanto País líder da América Latina, desempenha importante papel na preservação e proteção dos direitos humanos. ${ }^{2}$

Um dos grandes avanços e conquistas do Brasil em 2017 foi a aprovação da nova Lei de Imigração, de forma a revogar o antigo Estatuto do Estrangeiro de 1980.

A nova legislação tem por finalidade humanizar as políticas de acolhimento dos estrangeiros no território brasileiro, principalmente em períodos de grandes tensões e conflitos internacionais em que o Brasil adota políticas a serem seguidas pelos demais Estados, na forma de acolhimento de sírios e haitianos.

Vale destacar que a própria crise humanitária na Venezuela causa reflexos nas fronteiras brasileiras, com o ingresso de venezuelanos através de nossas fronteiras. Resta saber se as políticas públicas voltadas à aplicação de tais direitos serão observadas pelo Brasil.

Ao examinarmos as conclusões publicadas pela Human Rights Watch sobre o Brasil, é possível observar que atualmente passamos por um período de retrocessos em relação à proteção aos Direitos Humanos, especialmente no que diz respeito a problemas com a violência policial, a falta de segurança nos presídios, além de torturas e maus-tratos sofridos pelos detentos.

2 HUMAN RIGHTS WATCH. Brasil-eventos de 2016. Nova Iorque, 2016. Disponível em: <https://www.hrw.org/pt/world-report/2017/country-chapters/298766>. Acesso em: 23 abr. 2017. 
Outro aspecto que chama a atenção é o debate, existente no Congresso Nacional e na própria sociedade, em relação à possibilidade da redução da maioridade penal, em uma clara afronta aos direitos das crianças.

Interessantes são as conclusões em relação aos direitos de liberdade de expressão, liberdade na internet e privacidade. O Relatório reconhece a importância do Marco Civil da internet, o qual coloca o Brasil na vanguarda da proteção e regulamentação de tais direitos. Inclusive, dentro da Organização das Nações Unidas, o Brasil é um constante incentivador de políticas voltadas ao direito à privacidade.

Não obstante, o Relatório aponta para determinados atos isolados e decisões judiciais e que procuram limitar o direito à livre expressão, como o episódio do bloqueio do aplicativo Whatsapp em 2015, a prisão de um representante do Facebook ante a negativa de a empresa entregar determinadas informações às autoridades policiais, e as perseguições a jornalistas.

Da mesma forma, questiona-se a ausência de uma legislação mais clara e objetiva no sentido de permitir à mulher o direito ao aborto. A ilegalidade de tal prática, muitas vezes, faz com que mulheres busquem procedimentos ilegais para realizá-la, colocando-as em risco de morte.

Entre outros temas, ressaltam-se as constantes violações aos trabalhadores decorrentes de conflitos no campo e as ameaças de retrocessos na área dos direitos sociais e trabalhistas. Isso sem comentar sobre o debate existente no Congresso Nacional que procura retirar os direitos dos trabalhadores, como as reformas trabalhista e previdenciária.

Portanto, ainda que a Human Rights Watch atue de forma limitada, vez que é caracterizada como uma Organização Não Governamental e composta por membros da sociedade civil organizada, ela tem por objetivo atuar na defesa dos direitos humanos, tornando-se um grande instrumento em relação à proteção e aplicação dos direitos humanos.

O seu Relatório, elaborado em 2017, aponta para as graves violações existentes no Brasil quanto aos direitos humanos e, quiçá, sirva como um alerta a nós - brasileiros - sobre o que nos espera nos próximos anos.

Curitiba, PR, outono de 2017

Eduardo Biacchi Gomes

Professor do PPGD UniBrasil 
